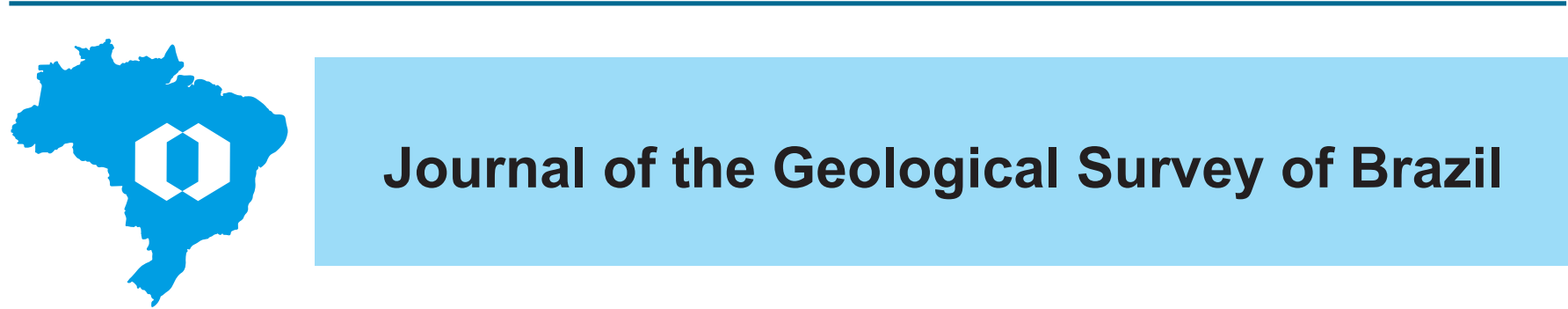

\title{
Classification of geo-mining heritage based on anthropogenic geomorphology
}

\author{
Paulo de Tarso Amorim Castro ${ }^{*{ }^{*}}$, Stênio Toledo Nascimento ${ }^{1,2}{ }^{(1)}$, Suzana Fernandes de Paula ${ }^{(\mathbb{C})}$ \\ ${ }^{1}$ Escola de Minas, Universidade Federal de Ouro Preto. Degeo - Campus Morro do Cruzeiro s/n. Ouro Preto - MG, Brazil, CEP: $35400-000$ \\ ${ }^{2}$ Instituto de Geociências, Universidade Federal de Minas Gerais. Av. Antônio Carlos, 6627, Pampulha - Belo Horizonte - MG, Brazil, CEP: $31270-901$. \\ Independent consultant, Ouro Preto - MG, Brazil, CEP: 35400-000.
}

\begin{abstract}
Studies on mining heritage and geoheritage walk different paths. While the former is based on a more cultural bias, the latter has its bases and conceptions geared towards the natural. However, the concept of landscape, which merges the natural and the cultural, connects the two concepts of heritage, enabling the conception of mixed heritage, namely, geo-mining. Based on the principle that mining interventions on the natural landscape can result in outcrops of features and aspects of geodiversity relevant for the understanding of regional evolutionary history, this article analyzes geo-mining heritage based on concepts of anthropogenic geomorphology. A geo-mining classification with three types is proposed based on the intensity and extent of anthropic alterations on the geoforms.
\end{abstract}

Article Information

Publication type: Research papers Received 7 November 2020 Accepted 6 January 2021 Online pub. 26 January 2021 Editor: K.L. Mansur

\section{Keywords:}

Geoheritage;

Mining heritage

Anthropogenic action;

Mining landscape

\section{${ }^{*}$ Corresponding author \\ Paulo de Tarso Amorim Castro \\ E-mail address: paulo de tarso@ufop.edu.br}

\section{Introduction}

The Earth is transformed through time. In the history of geological science, this observation comes from the writings of Nicolaus Steno, in the 17th century. Broadened by the vigorous, consistent and systematized work of James Hutton and Charles Lyell in the following two centuries, it was such an observation that provided support for the texts of Charles Darwin. However, the finding that humanity was an agent of transformation capable of interfering in and transforming the spheres located on the Geosphere was down to Vladimir Vernadsky at the beginning of the 20th century. This idea of humanity's capacity for transformation did not have primacy in Vernadsky, as others had already made this observation (e. g. Lyell cited by Peloggia and Ortega 2016, Eschwege 1833, cited by Fonseca and Sobreira 2001, Sherlock 1922). However, Vernadsly devoted himself to the topic more diligently, including using radio programs to spread these concepts. In the eagerness of humanity to obtain a lasting foundation of food, comfortable habitations, and rapid forms of transportation and communication, humans have taken a wide variety of living organisms and resource materials for themselves. The use of georesources reached a high intensity and was spread around the planet through the industrial revolution and that of modern agriculture and livestock. As a result, there have been modifications to the landscape, whether in urban regions or in regions far from urban centers.

Mining activities are among the most markedly intensive in landscape modification, leaving a long history of records on the Earth's surface. There are remnants of mining from 41,000 years ago in Egypt (Vermeersch 2005) and Swaziland (Beaumont 1973). In Latin America, signs of mining from around 12,000 years ago have been found in Chile (Salazar et al. 2011). The anthropic effects on the surface of the Geosphere caused by mining processes, whether concentrated or spread across a region, may result in peculiar surface features and accumulations of materials that interfere in the natural characteristics of a site or region. Such activity partially established the bases of what Sotchava (1977) defined as an anthropogenic landscape, being that which results from the interaction between the Geosphere and the anthroposphere. The conception of Anthropogenic Geomorphology (Szabó et al. 2010) also arose from these relationships. Anthropic interference can expose significant geological features, which would otherwise not be available to human access (for more information concerning the subject see Drew 1983, Goudie 
1993 and, information related to mining as geodiversity mining heritage see Von Ahn and Simom 2017). Peloggia (1998) indicates that anthropic intervention in the dynamic of nature results in consequences that can be grouped into three levels of approach. The first level is associated with the occurrence of transformations on the relief, that is, modifications related to landforms. The second level corresponds to alterations in the geomorphological dynamic, and the third level is related to the formation of deposits that may have been developed as a result of human agency. Price et al. (2011) and Peloggia et al. (2014) established a taxonomy of features on technogenic ground, providing a foundation for advances in the understanding of human interventions on the landscape and incorporating the anthropogenic dimension into cartographic surveys.

\subsection{Modification of the landscape through mining}

Mining stands out among the anthropogenic actions that contribute to landscape modification. The geosphere provides humans with more weather-resistant materials that allow the construction of towns and cities with longer-lasting facilities. In addition, some geomaterials are inputs for modern agriculture. If on the one hand mining contributes to the configuration of technogenic features in urban centers, on the other hand, it is also responsible for landscape modifications at the sites of georesource extraction. Thus, upon modifying the landscape, the removal of georesources contributes to generating rocky expositions that would not otherwise be visible. Some may turn out to be unique expositions with relevance for geoheritage.

There is no agreement among those that study geoheritage in respect to the definition of what geo-mining heritage would be. There are authors like Brilha (2016) that suggest that geoheritage should be distinct from other forms of heritage. Despite having direct connections with rocky expositions, as is the case of elements of mining heritage and archeological heritage, they are subject to distinct methodological procedures and analyses, constituting diverse cognitive fields. Others, such as Nascimento and Castro (2019) and Cordeiro (2010), understand that mining heritage can aggregate natural elements such as geomaterials, as well as documental, architectonic and immaterial elements, although they do not indicate the existence of geo-mining heritage. There are also those such as Puche Riart (2000) and Cañizares Ruiz (2011) that consider both geological heritage and mining heritage as one bivalent heritage category.

The geo-mining heritage associated with anthropogenic geomorphology can be recognized on mining landscapes or those exposed through intensive mining activities. They are recognized as significant from the geological or geomorphological perspective by institutions and research groups focused on geoheritage studies. Moreover, heritage value is intensified when local societies identify themselves with landscapes presenting a strong anthropogenic influence. Peloggia (2018) discussed these aspects in the light of Brazilian legislation and compiled the contribution of several national authors in aspects related to landscape modification and classified the initiatives into different categories.

The search for sites of human heritage classified as geoheritage carried out by Migori (2018) recognized that among the 206 natural sites classified as World Heritage by UNESCO, 90 had geoheritage references. On the other hand, Castro (2018), in an analysis conducted on the UNESCO World
Heritage list of cultural or mixed heritage (encompassing both natural and cultural criteria), recognized only 28 sites as being relevant for geo-mining heritage, which is $2.56 \%$ of all sites. All of these are framed by their cultural aspects. No sites were found that registered the interaction between mining activities and geodiversity.

\section{Methodological References}

The method used in the classification of geo-mining heritage linked to anthropogenic geomorphology follows the principles of Price et al. (2011) and Sherlock (1922) in regard to anthropogenic geomorphology. It starts with the description of the geoforms built or modified by human action, their dimensions, their location, as well as the possibility of reshaping and requalification for other uses.

There is no specific base containing, in a systematic way, data on mining assets or geosites that are associated with mining. Therefore, a wide review of the subject was carried out in sources of information scattered in the literature. The focus was to investigate those areas where mining, mainly in the open pit type and old or historic mines abandoned or deactivated, was active and resulted in landscape modification. Several sources of information on sites considered important as mining heritage and geoconservation were examined. As a basis for the analysis of mining heritage, the list of Unesco World Heritage Sites (UNESCO 2020) and the works of Migori (2018) and Castro (2018) were reviewed. An attempt was also made to analyze the lists contained in some compilation works of geological heritage (e.g. Dingwall et al. 2005) and which had mining activities as the basis of their exhibition The vast literature on mining heritage organized by Sociedad Española for the Defensa del Patrimonio Geológico y Minero (SEDPGYM 2020) and in the Geological Society (2020) was visited, as well as information about mining in the United Kingdom (e.g. The Mining Institute 2019, Mining Exploration and Mining History 2019, Cornish Mining World Heritage Site 2019).

In Brazil, in addition to the national geosite base (e.g. Geological and Paleontological Sites of Brazil - Sítios Geológicos e Paleontológicos do Brasil - Schobbenhaus et al. 2002, Winge et al. 2009, 2013, CPRM 2019, special focus was given to two regions with historical records of mining activity: the highlands of the southern center of Minas Gerais, near Ouro Preto, the birthplace of the gold cycle, in the 17th to 19th centuries and the Chapada Diamantina, in Bahia, where diamond was the main agent of interiorization of the population in the 18th and 19th centuries. In the Ouro Preto region there are several works regarding the mining heritage and landscape modification (e.g., Fonseca and Sobreira 2001, Sobreira 2014, Barbosa et al. 2018) and in Chapada Diamantina, mainly in the Igatu and Lençois region (e.g., Santos et al. 2010, Russ and Nolasco 2012, Nolasco 2012).

\section{Results}

From the analysis carried out on the geoheritage and mining heritage sites, based on elements substantiated in the anthropogenic geomorphology, three landscape classes were defined as follows:

1) Re-qualifiable local landscape: places in which the mining activity generates localized pits and mine benches, where the concentration of the mineral resource and the 
geomorphological conditions enable low-cost, normally mechanized, extraction. Worked anthropogenic geoforms can be found (in the classification of Price et al. 2011), represented by pits and constructed lands such as spoil heaps. Anthropogenic geoforms are easily recognizable. Two factors contribute to the closure of extractive activities: mineral exhaustion and the conflict between mining and the predominant use of the territory, which is commonly due to the expansion of urban centers. The requalification of the pits and mine benches is necessary and desirable, with their usage normally aimed at tourism and leisure, and, occasionally, for the expansion and maintenance of forested areas;

2) Regional landscape intensely transformed through mining activities: these are regions in which the mining activity is little mechanized and widespread, with blasting, excavations, piling of waste material and the construction of aqueducts and mining flumes. Normally, they are associated with mineral resources of very high value to weight ratio, such as silver or gold, which encourage manual extraction or semimechanized work that is scattered and irregular. The intensity of this mining produces several anthropogenic geoforms whose dimensions are relatively small. The result is a mosaic of excavated and produced land, represented by heaps of sterile rocks, which increases the roughness of the terrain. In many cases, this favors the settlement of sparsely populated regions, creating urban centers;

3) Regional landscape exhumed by regional mining activities: regions in which the mineral resources were completely exhausted, in which there have been no processes in use since the end of mineral exploration. Mineral extraction occurred using rustic processes with little industry, which were persistent over time, and there is no recovery of the modified areas. Given the shallow depth of mineral resources in regions where the exhumation of the paleosurface occurs, which is the physical expression of an ancient landscape, their extraction did not require intense mechanization. The result is the exhumation of a visible geological discontinuity (stratigraphic), which clearly marks the separation between geological materials that present cohesive characteristics and disparate mineral concentrations. In terms of anthropogenic geomorphology, excavations predominate, with the constructed ground being locally restricted.

The landscapes that are altered through mining over time have cultural and heritage value, and therefore come to compose geo-mining heritage of that locality or region. Table 1 presents examples of landscapes transformed through mining.
The first defined class, local re-qualifiable landscape, can be exemplified by the Municipal Park of Mangabeiras (Figure $1 \mathrm{~A})$, in the Serra do Curral mountains in Belo Horizonte, Minas Gerais (Brasil). In that area, there was an iron mine, which functioned until the 1970s (Ruchkys et al. 2012). The mining bench was requalified and today houses the administrative headquarters of the park and the Praça das Águas, which is a complex of socio-environmental programs that involve environmental awareness and valorization of the natural environment.

The Cumbe quarry, which was in activity from the middle of the 20th century extracting dolomitic marble for cladding in the region of Cachoeira do Campo, Ouro Preto (Brazil), is another example of this class. The extraction was shut down in the current decade as the rocks contain the oldest stromatolites in South America (Dardenne and Campos Neto 1975, Maciel 2014).

The Tanguá quarry (Figure 1B), in Curitiba, Paraná State (Brazil), was the source of rocks for paving and construction. After its shutdown, it was requalified, being transformed into an urban park (Liccardo et al. 2008).

Another example is the $80 \mathrm{~m}$-deep pit, $1000 \mathrm{~m}$ from the perimeter to the foothill of the Tianma Hill in Shanghai (China), which was an active quarry between 1950 and 2000, when it was abandoned. It currently houses the Shimao Shenkeng hotel, also known as the InterContinental Shanghai Wonderland Hotel, a five-star hotel on the outskirts of Shanghai (Ping et al. 2019).

A notable example in this class is Butchart Gardens, near Victoria, British Columbia (Canada). In 1909, gardens were created on the site of an exhausted limestone quarry, and they are one of the biggest regional attractions until today and recognized as a historic site in Canada (Canada's Historic Places 2019).

The second class, regional landscapes intensely transformed through mining activities, have various stand-out examples, such as the gold-mining areas to the south of the Quadrilátero Ferrífero, especially those in the mountains of the municipality of Ouro Preto, between Ouro Preto and Mariana (Minas Gerais, Brazil). Gold extraction in the mountains of Ouro Preto (Sobreira 2014, Nascimento 2016), (Figure 2A and 2B), and of Antônio Pereira (Nascimento 2016, 2019), (Figure $2 \mathrm{C}$ and $2 \mathrm{D}$ ), which began in the mid-17th century, modified the geomorphological configuration of these mountains. In the 18th century, the Serra de Ouro Preto gold mines provided the base for the main urban center in the Brazilian interior.

TABLE 1. Types of landscapes modified by mining and examples.

\begin{tabular}{l|l|l|l}
\hline Class & Examples & Location & References \\
\hline \multirow{4}{*}{$\begin{array}{l}\text { Re-qualifiable local } \\
\text { landscape }\end{array}$} & Parque das Mangabeiras & Belo Horizonte, Minas Gerais, Brazil & Ruchkys et al. (2012) \\
\cline { 2 - 4 } & Pedreira do Cumbe & Ouro Preto, Minas Gerais, Brazil & $\begin{array}{l}\text { Dardenne and Campos Neto } \\
(1975), \text { Maciel (2014) }\end{array}$ \\
\cline { 2 - 4 } & Pedreira Tanguá & Curitiba, Paraná, Brazil & Liccardo et al. (2008) \\
\cline { 2 - 4 } & Tianma Hill Quarry & Shanghai, China & Ping et al. (2019) \\
\cline { 2 - 4 } $\begin{array}{l}\text { Regional landscape } \\
\text { intensely transformed } \\
\text { through mining activities }\end{array}$ & Butchart Garden & Victoria, British Columbia, Canada & Canada's Historic Places (2019) \\
\cline { 2 - 4 } $\begin{array}{l}\text { Regional landscape } \\
\text { exhumed by regional } \\
\text { mining activities }\end{array}$ & Serra de Antônio Pereira & Ouro Preto e Mariana, Minas Gerais, Brazil & Nascimento (2016) \\
\cline { 2 - 4 } & Las Médulas & El Bierzo, Castilla e León, Spain & Sánchez-Palencia et al. (2000) \\
\cline { 2 - 4 } & Cerro del Hierro & Andaraí, Bahia, Brazil & Russ and Nolasco (2012) \\
\hline
\end{tabular}


The gold mining carried out by the Romans in Las Médulas, on the border between Galícia, Astúrias and Castela and León, in Northwest Spain, is distributed across approximately 1,200 hectares. According to Sánchez-Palencia et al. (2000), around 100 million $\mathrm{m}^{3}$ of material was removed in the first two centuries of the Christian era, being considered the largest open-air gold mine of the Roman Empire. It is now a UNESCO World Heritage site, recognized for cultural criteria (Figure 3)

The third class of landscape refers to those regions in which mining provoked the exhumation of paleosurfaces. Two examples stand out - Igatu, in the Andaraí district of Bahia (Brazil) and the Natural Monument of Cierro del Hierro, in the Serra Norte de Sevilha Natural Park (Spain).

Igatu is a record of diamond and carbonado extraction, this being an amorphous variety of diamond, in the Chapada Diamantina, since the 17 th century. Diamond and carbonado extraction work was essentially not mechanized and profoundly modified the regional landscape (Nolasco 2012).
Two aspects of the diamond mine contributed to the intense landscape modification in Igatu: the sale price of diamonds, which increases exponentially with their weight, and the subsequent extraction processes that preserve their physical integrity. Thus, the mining of diamonds is carried out in alluvial and colluvial deposits in drainage headwaters, accumulated on Proterozoic rocky substrate on the mountainous slopes of the Chapada Diamantina. Extraction occurred in unconsolidated material, removing the pedological material that supported the previously existing vegetation, exhuming the rocky surface (Nolasco 2012, Russ and Nolasco 2012) (Figure 4).

In Cerro del Hierro, San Nicolás del Puerto, Andalusia (Spain), iron extraction was responsible for the transformation of the landscape (Figure 5). Moreno et al. (2008) describe that the iron mining carried out from the pre-Roman period to the mid-20th century created a landscape intensely altered by anthropic action. The iron was concentrated in a surface of stratigraphic discontinuity between Eocambrian limestone

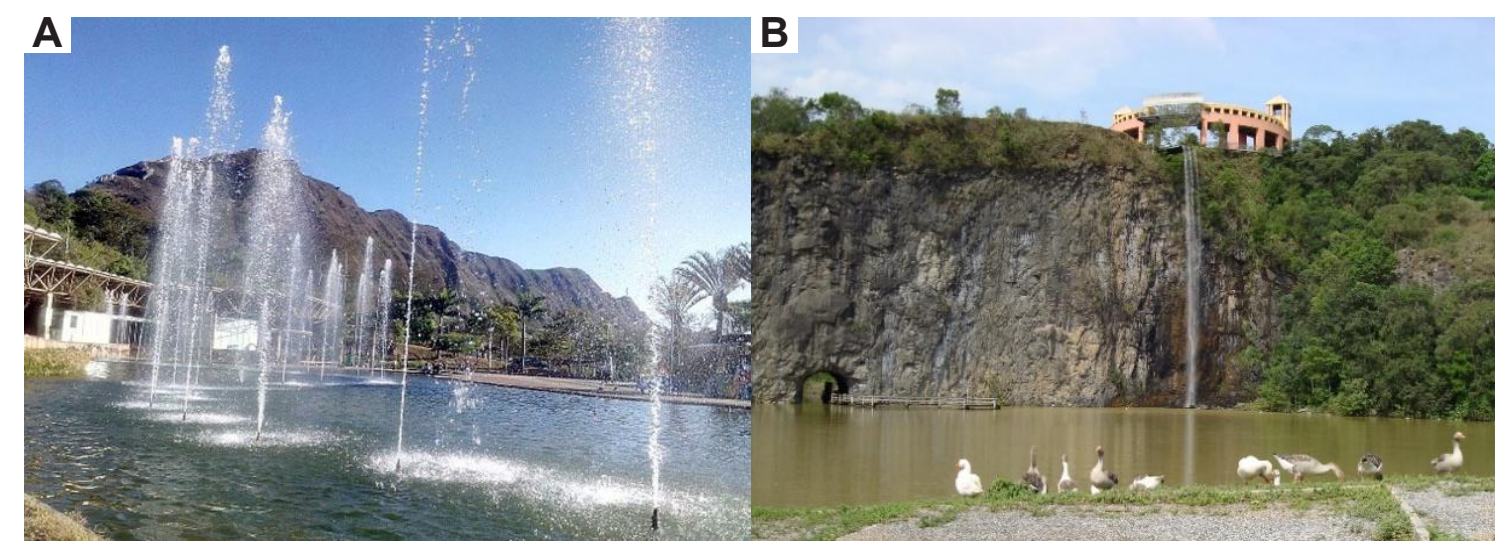

FIGURE 1. Examples of Class 1 Geo-mining Heritage. A - Municipal Park of Mangabeiras, in Belo Horizonte, requalifying an old iron ore mining at the foot of Serra do Curral (photo Eliezer S. Costa). B - Tanguá quarry, in Curitiba, an old quarry of gneiss and diabase re-qualified for tourist use, preserving the exposure of rocks (photo by Leonardo Stábile)

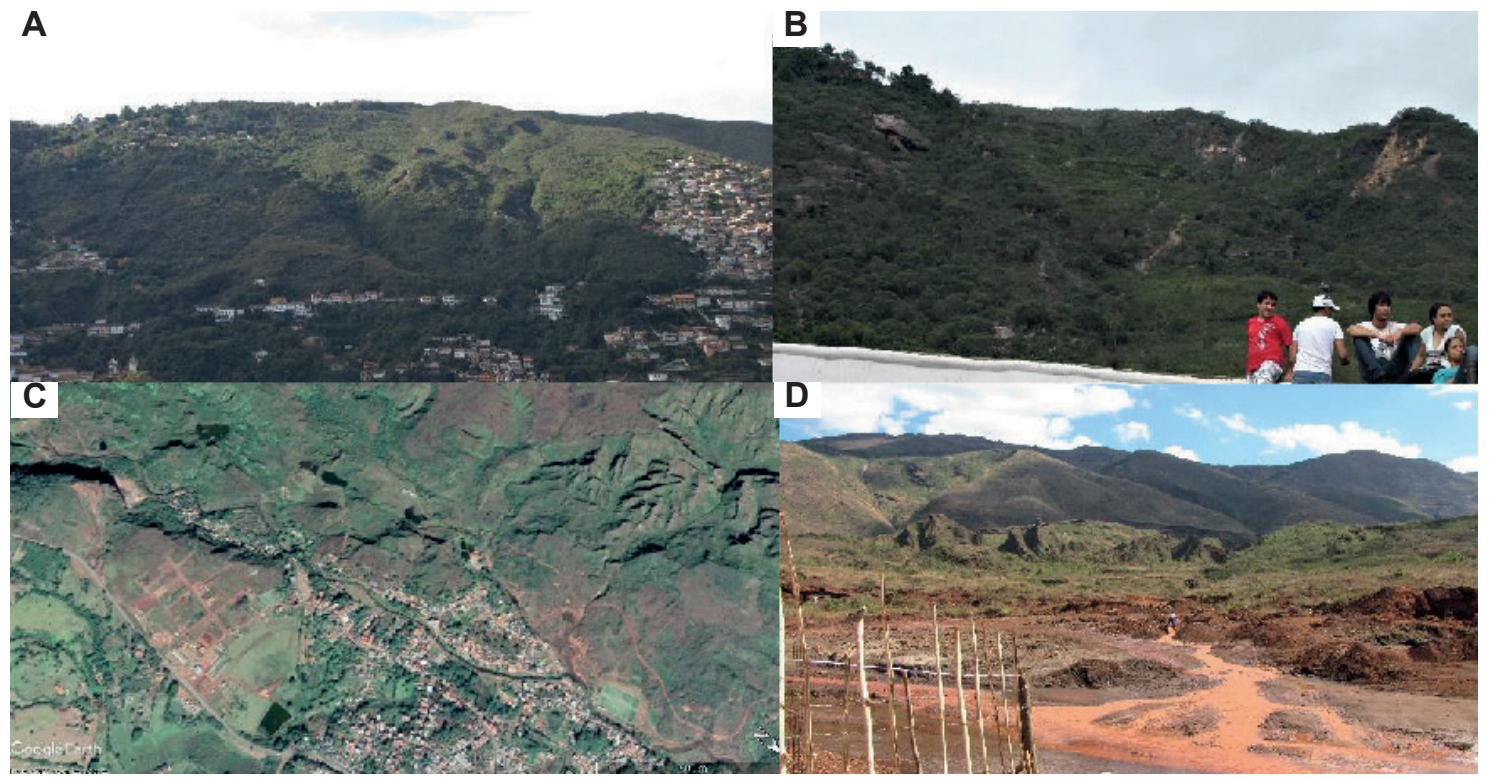

FIGURE 2. Examples of Class 2 Geo-mining Heritage. A - image of the Serra de Ouro Preto showing areas of urban occupation interspersed with areas of dismantling caused by gold mining throughout the 18th century. Note the areas of great roughness that result from dismantling by mining in the neighborhoods of Alto da Cruz and Padre Faria; in the background the Morro da Queimada. B - details of part of the Ouro Preto mountain. C - rough relief, caused by intensive gold mining, west of Antônio Pereira district, Ouro Preto (Google Earth 2020). D - in the middle plane, relief with pinnacles, resulting from the intense mining of gold. 


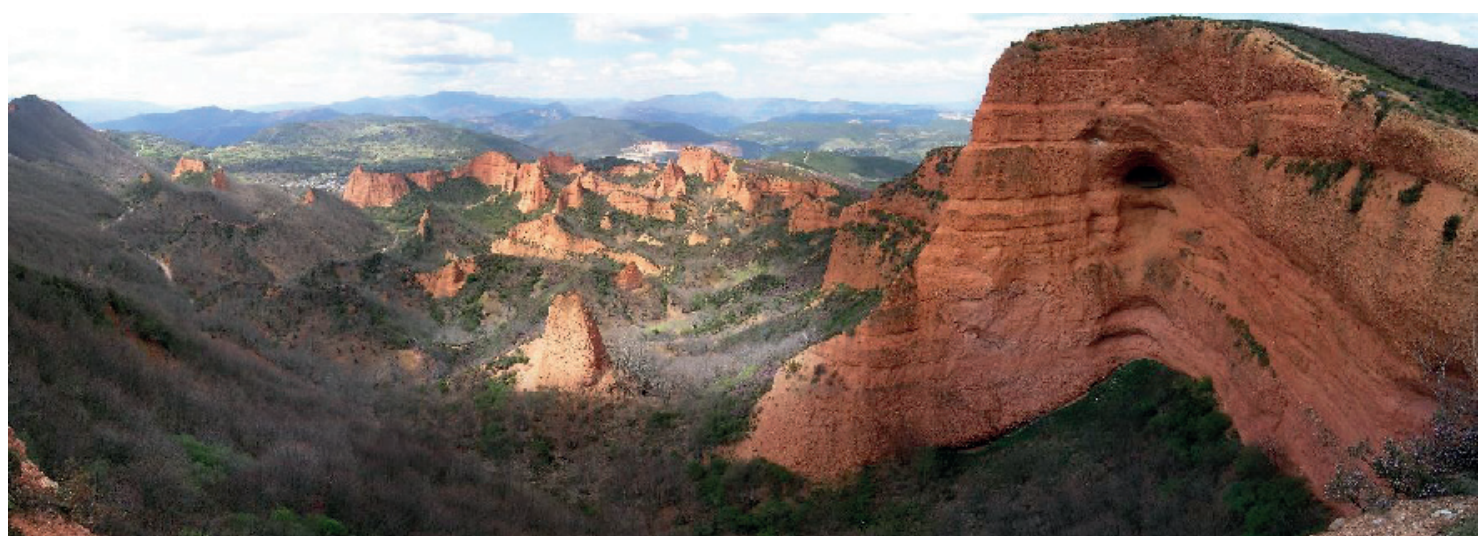

FIGURE 3. Class 2 Geo-mining heritage. Anthropogenic geoforms from Las Médulas (Spain), an ancient gold mine from the Roman period, active throughout the $1^{\text {st }}$ and $2^{\text {nd }}$ century AD (photo Alessio Damato).
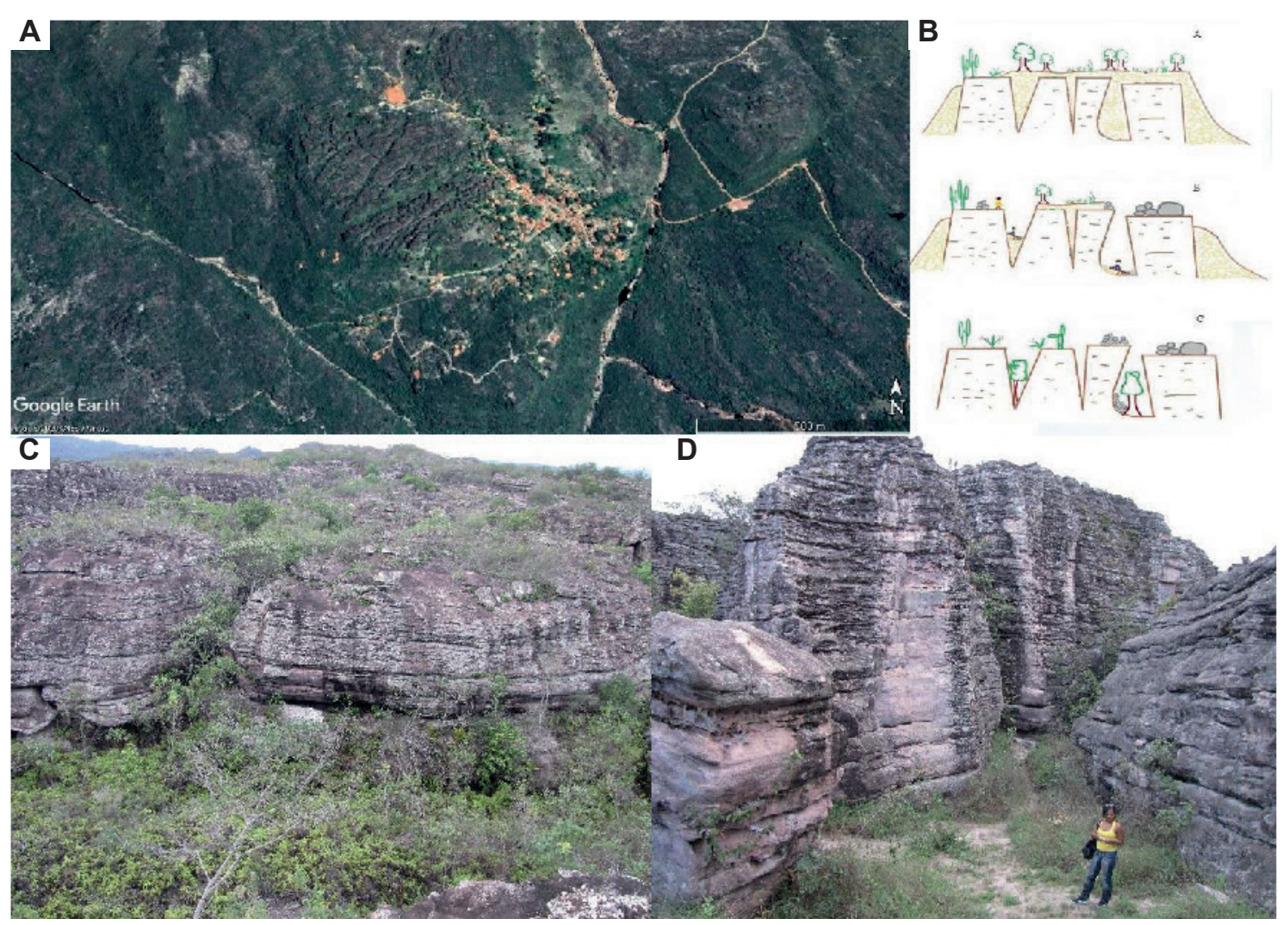

FIGURE 4. Class 3 Geomineer Heritage. A - the village of Igatu and the anthropogenic landscape generated by the extractive action of the diamond and carbonado (Google Earth 2020). B - an evolutionary scheme of diamond mining action over 200 years and the generation of the current landscape (Russ and Nolasco 2012). C and D - the current landscape of the region, showing the exposure of rocks with shrub cover and arboreal vegetation occupying the depressions caused by the emptying of fractures and removal of colluvial-alluvial material by mining.

and Neocambrian mudstone. Karst developed in the limestone that was formed in four stages, the most intense being in the Paleogene, when there was a new subaerial exposition that caused more extensive regional karstification, followed by the current, less developed karstic processes. The iron minerals are formed in the mudstone that fills the karst. The iron mine exhumed a significant part of the features of the exokarst formed in the Paleogene.

\section{Discussion}

The evolution of concepts in geoheritage and mining heritage has taken many paths. This is partly due to the segmentation of knowledge fields in heritage terms, in which there is a tendency to separate analysis of what is relatable to world heritage into two frameworks, the natural and the cultural. There are few UNESCO World Heritage sites classed as mixed; there were only 38 sites on the 2018 list, which corresponds to $3.48 \%$.

Industrial transformation processes of nature, as in the case of mining, were not initially understood as being the cultural expression of communities. The literature related to the historical evolution of the concept of mining heritage resided, initially, in mining processes, especially historical processes. Only later did it address the way of life and the values of the people of mining regions as an expression of collectiveness, 


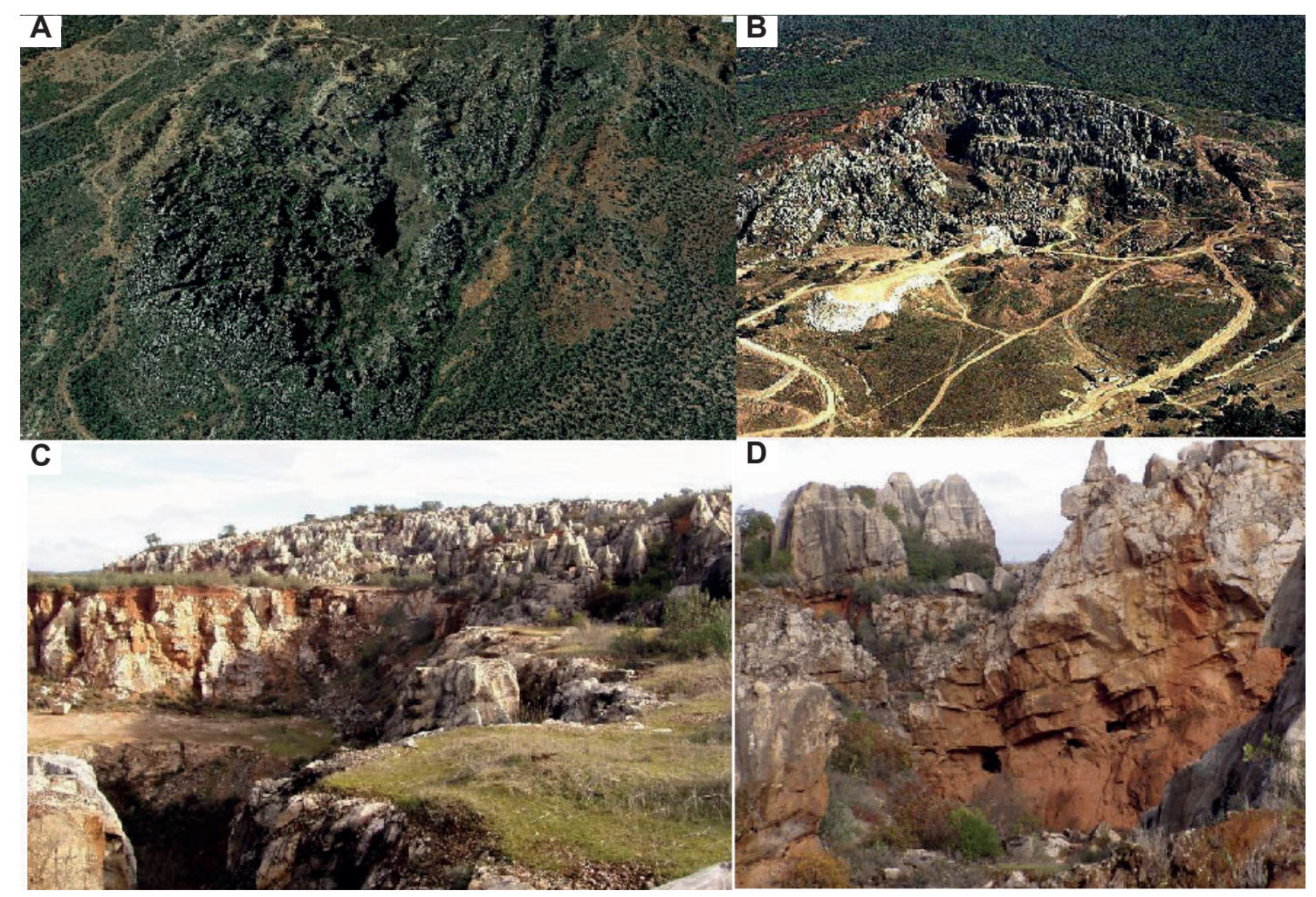

FIGURE 5. Class 3 Geo-mining Heritage. A and B - the general characteristics of the exhumed area, which was generated by mining activities in Cerro del Hierro, Spain (photo A: Google 2020, photo B: J. Alonso). C and D - features of the exhumed paleogenic paleokarst, with cavities emptied by the extraction process.

and, therefore, their heritage. Subsequently, the documents of mining industries were understood as part of the heritage, and, more recently, the landscape, encompassing the natural aspect, transformed through mining, with its industrial buildings and homes, and its form of construction as part of mining heritage (Puche Riart 2000). On the other hand, the origin of geoheritage and its importance occurred based on the understanding that relevant examples of geological materials (in situ and ex situ), geoforms and their formation processes became important, as they reflect and portray the history of the Earth. Its origin comes from the understanding of the natural heritage of the abiotic component, following the steps of humanity in the conservation of biotic nature since the middle of the 20th century.

The connection between Geoheritage and Mining Heritage has the concept of landscapes that incorporate elements of the natural and the anthropic as an essential element. By associating elements of geoheritage and mining heritage, in the initial analysis, it is recognized that there is a relationship between geomaterials and the extraction processes used throughout the human history. Some of these processes have been used intensely for decades and have played a role in forging a mining culture in certain societies. In the final analysis, this relationship between geomaterials and extraction processes imprinted modifications on the landscapes, which can be described in light of the concepts of anthropogenic geoforms, some of which, given their characteristics, are so conspicuous that they can be distinguished and classified according to their main types.

Some of the most significant examples of geosites and elements of geological heritage (Brilha 2016), such as the mega crystals of Naica (Garcia-Ruiz et al. 2007) and the large trilobites of Canelas-Arouca, in Portugal (Gutiérrez-Marco et al. 2009), were only able to be revealed through mining. There remains a field to be explored in regard to the classification of anthropogenic geomorphology features when focusing on mining, especially open-pit mining or mining at shallow depths.

\section{Conclusions}

The concept of humans as geological agents, capable of transforming the Earth, has at Vernadsky, not the primacy, but one of its main disseminators in the first half of the 20th century (Vernadsky 1998). At the end of that century, these concepts were expanded, and methods of classification and mapping of forms created and/or modified by humans were applied. Where mining produces and changes geoforms it ends up generating mining landscapes, incorporating the anthropic to the natural. In these places, there is the possibility of a connection between Geoheritage and Mining Heritage.

This text classifies the landscapes generated by anthropogenic mineral geomorphology consisting of three classes of landscapes, determined by their expression in terms of typologies of anthropogenic geoforms constructed, excavated, and exhumed.

\section{Acknowledgments}

The authors would like to thank the anonymous reviewer for the suggestions that helped to clarify parts of the text. Paulo de Tarso Amorim Castro would like to thank the National Council for Scientific and Technological Development (CNPq - Conselho Nacional de Desenvolvimento Científico e Tecnológico), 
for research grant 2. Stênio Toledo Nascimento would like to thank IGC/UFMG for the support of his capacitation at doctorate level. The authors are members of the Geodiversity, Geological Heritage and Geoconservation Research Group (dgp.cnpq.br/dgp/espelhogrupo/ 0070510881078351).

\section{References}

Barbosa V.S.B., Lima H.M., Laudares S., Fonseca B.M. 2018. Mine Closure in Ouro Preto: the remnants of the 18th century gold rush and the tourism as an economic opportunity. Revista da Escola de Minas, 72, 39-46.

Beaumont P.B. 1973. The ancient pigment mines of Southern Africa. Journal of Science, 69, 140-146.

Brilha J. 2016. Inventory and quantitative assessment of geosites and geodiversity sites: a review. Geoheritage, 8, 119-134. https://doi. org/10.1007/s12371-014-0139-3

Canada's Historic Places. 2019. Butchart Gardens National Historic Site of Canada. Available on line at: https://www.historicplaces.ca/en/ rep-reg/place-lieu.aspx?id=7821\&pid=0/ (accessed on 15 November 2019)

Cañizares Ruiz M.C. 2011. Protección y Defensa del Patrimonio Minero en España. Scripta Nova, Revista Electrónica de Geografía y Ciencias Sociales, 15, 361. Available on line at: http://www.ub.es/geocrit/sn/sn361.htm (accessed on 8 October 2020)

Castro P.T.A. 2018. Patrimônio Geo-Mineiro: quando a interrelação entre eles se evidencia. Caderno de Geografia, 28, 39-54. https://doi. org/10.5752/P.2318-2962.2018v28nespp39

Cordeiro J.M.L. 2010. Património geomineiro em Portugal. In: Neiva J.M., Cotelo, Ribeiro A., Mendes V., Noronha F., Ramalho M. (eds.). Ciências Geológicas - Ensino e Investigação e sua História. Porto, 2, p. 483-490.

Cornish Mining World Heritage Site. 2019. Available on line at: https:// www.visitcornwall.com/things-to-do/history-and-heritage/worldheritage-site (accessed on 24 November 2019)

CPRM - Serviço Geológico do Brasil. 2019. Geossit - cadastro de sítios geológicos. Available on line at: https://www.cprm.gov.br/geossit/ (accessed on 13 march 2019)

Dardenne M.A., Campos Neto M.C. 1975. Estromatólitos colunares na Série Minas (MG). Revista Brasileira de Geociências, 5, 2, 99-105. Available on line at: http://ppegeo.igc.usp.br/index.php/rbg/article/ view/12397 (accessed on 14 January 2021)

Drew D.P. 1983. Man-Environment processes. London, George Allen \& Unwin, 135 p. https://doi.org/10.1111/j.0028-8292.1983.tb00149.x

Dingwall P., Weighell T., Badman T. 2005. Geological World Heritage: A Global Framework. A contribution to the Global Theme Study of World Heritage Natural Sites IUCN_The World Conservation Union. Available on line at: https://www.iucn.org/content/geological-worldheritage-a-global-framework (accessed on 11 October 2019)

Fonseca M. A., Sobreira F. G. 2001. Impactos físicos e sociais de antigas atividades de mineração em Ouro Preto, Brasil. Geotecnia, Lisboa, 92, 5-28, 2001. http://www.repositorio.ufop.br/handle/123456789/4105

Garcia-Ruiz J.M., Villasuso R., Canals A., Otáfora F. 2007. Formation of natural gypsum megacrystals in Naica, Mexico. Geology, 35, 327-330. https://doi.org/10.1130/G23393A.1

Goudie A. 1993. Human influence in geomorphology. Geomorphology, 7, 37-59. https://doi.org/10.1016/0169-555X(93)90011-P

Gutiérrez-Marco J.C., Sá A.A., García-Bellido D.C., Rábano I., Valério M. 2009. Giant trilobites clusters from the Ordovician of Portugal. Geology, 37, 443-446. https://doi.org/10.1130/G25513A.1

Liccardo A., Piekarz G.F., Salamuni E. 2008. Geoturismo em Curitiba. Curitiba, Mineropar, $122 \mathrm{p}$.

Maciel V.M. 2014. Análise da geodiversidade da bacia do rio Maracujá, e suas adjacências, nos arredores de Santo Antônio do Leite e Cachoeira do Campo. 2014. Graduation work, Escola de Minas, Universidade Federal de Ouro Preto, Ouro Preto, 79 p.

Migori P. 2018. Geoheritage and world heritage sites. In: Reynolds E., Brilha J. (ed.) Geoheritage - assessment, protection, and management. Amsterdam, Elsevier. Chapter

13, p. 237-249. http://dx.doi.org/10.1016/B978-0-12-809531-7.00013-7

Mining Exploration and Mining History. 2019. Available on line at: https:// www.aditnow.co.uk/ (accessed on 26 November 2019)
Moreno C.G., Sáez R.R., Gonzalez F.B. 2008. Guia geológica e itinerários: Parque Natural Sierra Norte de Sevilla. Sevilla. Consejería de Medio Ambiente, Red de Espacios Naturales Protegidos, 210 p.

Nascimento S.T. 2016. Geodiversidade e Geomorfologia Antropogênica na Região das Minas de Ouro no Anticlinal de Mariana, MG. MSc Dissertation, Escola de Minas, Universidade Federal de Ouro Preto, Ouro Preto, 107 p. http://www.repositorio.ufop.br/ handle/123456789/7319

Nascimento S.T., Castro P.T.A. 2019. Modelagem da geodiversidade para o anticlinal de Mariana, sudeste do Quadrilátero Ferrífero, Minas Gerais, Brasil. Geologia USP, Série científica, 19, 117-127. https://doi. org/10.11606/issn.2316-9095.v19-134534

Nolasco M.C. 2012. Paisagens a Diamante: Chapada Diamantina, BA. In: Congreso Internacional Sobre Patrimonio Geológico y Minero, 13, 345-378.

Peloggia A.U.G. 1998. O homem e o ambiente geológico: geologia, sociedade e ocupação urbana no Município de São Paulo. São Paulo, Xamã, $271 \mathrm{p}$.

Peloggia A.U.G. 2018. Os registros geológicos da agência humana como categoria temática de patrimônio. In: Simpósio Nacional de Ensino e História de Ciências da Terra - EnsinoGeo2018, 8, 614-620.

Peloggia A.U.G., Ortega A.M. 2016. Lyell, a agência geológica humana e o antropoceno: em busca de uma epsitemologia geológica e arqueológica. Revista UNG - Geociências,15, 2, 106-127. Available on line at: http://revistas.ung.br/index.php/geociencias/article/view/2435 (accessed on 15 January 2020)

Peloggia A.U.G., Silva E.C.N., Nunes J.O.R. 2014. Technogenic landforms: conceptual framework and application to geomorphologic mapping of artificial ground and landscape as transformed by human geological action. Quaternary and Environmental Geosciences, 5, 28-40.

Ping L., Lai Z., Sen C., Xueqiang Z., Tao Y., Di C., Qi yan F. 2019. Main challenges of closed/abandoned coal mine resource utilization in China, Energy Sources, Part A: Recovery, Utilization, and Environmental Effects, 42, 2822-2830. https://doi.org/10.1080/15567 $\underline{036.2019 .1618992}$

Price S. J., Ford J. R., Cooper A. H., Neal C. 2011. Human as major geological and geomorphological agents in the Anthropocene: the significance of artificial ground in Great Britain. Philosophical Transactions of the Royal Society A, 369, 1056-1086.

Puche Riart O. 2000. La conservación del Patrimonio Geológico y Minero. In: Ciento cincuenta años (1849-1999). Estudio e investigación en Ciencias de la Tierra. Madrid. Instituto Geológico y Minero de España, $101 \mathrm{p}$.

Ruchkys U.A., Machado M.M.M., Castro P.T.A., Renger F.E., Trevisol A. 2012. Geoparque Quadrilátero Ferrífero, Minas Gerais. In: Schobbenhaus C., Silva C. (ed.) Geoparques do Brasil: propostas. Rio de Janeiro, Serviço Geológico do Brasil, p. 183-220. http://rigeo.cprm. gov.br/jspui/handle/doc/1209

Russ B.R., Nolasco, M.C. 2012. Revelando a Geodiversidade através da educação ambiental: percepção de estudantes sobre o Geossítio Manga do Céu. Anuário do Instituto de Geociências - UFRJ, 35, 271280. http://dx.doi.org/10.11137/2012_1_271_280

Russ B.R., Nolasco M. C. 2012. Vila de Igatu, Bahia-Brasil: história ambiental de um patrimônio geominero a diamantes - 1846 - 2012. In: Congreso Internacional Sobre Patrimonio Geológico y Minero, 13, p. 401-422.

Salazar D., Jackson D., Guendon J.L., Salinas H., Morata D., Figueroa V., Manríquez G., Castro V. 2011. Early evidence (ca. 12,000 BP) for iron oxide mining on Pacific coast of South America. Current Anthropology, 52, 3, 463-475. Available on line at: https://www.journals.uchicago. edu/doi/10.1086/659426 (accessed on 15 January 2020)

Sánchez-Palencia F.J., Fernandez-Posse J., Fernandez Manzano A.O., Perez Garcia L.C. 2000. Las Médulas (León), La formación de un Paisaje Cultural Minero. Boletín Geológico y Minero, 109, 589-598.

Santos L.T.S.O., Vasconcelos M.P., Rodrigues D.P., Nolasco M.C, Jesus T.B. 2010. Conseqüências da atividade garimpeira de diamante na Bacia do rio Coisa Boa, Vila de Igatu - Andaraí - BA. Revista de Biologia e Ciências da Terra, 10, 2, 01-11. Available on line at: http://joaootavio.com.br/bioterra/workspace/uploads/ artigos/artigo 01 v10 n2-51561a085fabc.pdf (accessed on 14 January 2020)

Schobbenhaus C., Campos D.A., Queiroz E.T., Winge M., Berbert-Born M.L.C. (eds.). 2002. Sítios geológicos e paleontológicos do Brasil. 
Brasília, CPRM, DNPM, SIGEP, 554 p. http://rigeo.cprm.gov.br/jspui/ handle/doc/19846

SEDPGYM. 2020. Sociedad Española para la Defensa del Patrimonio Geológico y Minero. Available on line at: http://www.sedpgym.es/ (accessed on 8 October 2020)

Sherlock L. R. 1922. Man as a geological agent: an account of his action on inanimate nature. London, H.F. \& G. Witherby, 372 p.

Sobreira F. 2014. Mineração do ouro no período colonial: alterações paisagísticas antrópicas na serra de Ouro Preto, Minas Gerais. Quaternary and Environmental Geosciences, 5, 1. Available on line at: $\quad$ https://revistas.ufpr.br/abequa/article/download/34432/23233 (accessed on 28 June 2020)

Sotchava V.B. 1977. O estudo dos geossistemas. Métodos em Questão. 6. ed. São Paulo. $50 \mathrm{p}$.

Szabó J., Lórant D., Lóczy D. (eds.). 2010. Anthropogenic Geomorphology: a guide to man-made landforms. London, Springer, $260 \mathrm{p}$.

The Geological Society. 2020. 100 Great Sites. Available on line at: https://www.geolsoc.org.uk/100geosites (accessed on 26 June 2020)
The Mining Institute. 2019. Available on line at: https://mininginstitute.org. uk/ (accessed on 13 November 2019)

Vermeersch P.M. 2005. Middle Palaeolithic chert extraction structures in Egypt. Praehistoria, 6, 57-70.

Vernadsky V. I. 1998. The biosphere. New York, Copernicus. 192 p. DOI: 10.1007/978-1-4612-1750-3

Von Ahn M.M., Simon A.L.H. 2017. Geomorphological mapping and geodiversity: study at the Minas do Canaquã Geosite Protection Area (Brazil). Revista Brasileira de Geomorfologia, 18, 427-442. http:// dx.doi.org/10.20502/rbg.v18i2.1137

Winge M., Schobbenhaus C., Souza C.R.G., Fernandes A.C.S., Queiroz E.T., Berbert-Born M., Campos D.A. (ed.). 2009. Sítios Geológicos e Paleontológicos do Brasil. Brasília, CPRM, v. 2. http://rigeo.cprm.gov. br/jspui/handle/doc/19865

Winge M., Schobbenhaus C., Souza C.R.G., Fernandes A.C.S., Queiroz E.T., Berbert-Born M., Campos D.A. (ed.). 2013. Sítios Geológicos e Paleontológicos do Brasil. Brasília, CPRM, v. 3. http://rigeo.cprm.gov. br/jspui/handle/doc/19391 